\title{
Entrepreneurship Development in Higher Education Through Ve-Ice Carroli to Foster Student Entrepreneurial Interest
}

\author{
Idzaa Zubdatun Thoyyibah, Dian Candra Wati, Frizky Rahmadhani
}

Universitas Sebelas Maret, zubdatunidzaa@gmail.com

\section{Article History}

accepted 24/09/2019

approved 01/10/2019

published 01/12/2019

\begin{abstract}
This article aims to foster student entrepreneurial interest in the millennial era. It is through VeIce Carroli (Vegetables Ice Cream Carrot and Broccoli). The research method used is the study of literature. Data collection is done by studying books, literature, notes, and reports relating to the problem being solved. Literature sources in this study were obtained from books, journals, and research results. The results of this study include the process of identifying theories systematically, finding literature, and analyzing documents that contain information related to the research topic. The results of this study are in the form of the development of higher education entrepreneurship learning.
\end{abstract}

Keywords: Entrepreneurship, Ve-Ice Carroli, Students

\begin{abstract}
Abstrak
Artikel ini bertujuan untuk menumbuhkembangkan minat kewirausahaan mahasiswa di era milenial, salah satunya melalui Ve-Ice Carroli (Vegetables Ice Cream Carrot and Broccoli). Metode penelitian yang digunakan adalah studi literatur. Pengumpulan data dilakukan dengan studi buku, literatur, catatan, dan laporan yang berkaitan dengan masalah yang sedang dipecahkan. Sumber literatur dalam penelitian ini diperoleh dari buku, jurnal, dan hasil penelitian. Hasil penelitian ini mencakup proses mengidentifikasi teori secara sistematis, menemukan literatur, dan menganalisis dokumen yang berisi informasi yang berkaitan dengan topik penelitian. Hasil penelitian ini berupa bentuk pengembangan pembelajaran kewirausahaan perguruan tinggi.
\end{abstract}

Kata Kunci: Kewirausahaan, Ve-Ice Carroli, Mahasiswa

Social, Humanities, and Education Studies (SHEs): Conference Series https://jurnal.uns.ac.id/shes 


\section{PENDAHULUAN}

Motivasi dan minat pemuda Indonesia untuk melakukan kegiatan wirausaha saat ini menjadi pemikiran yang cukup serius dari berbagai belah pihak, baik dunia pendidikan, pihak pemerintahan, dunia perindustrian, bahkan sampai masyarakat. Berbagai cara dilakukan untuk menumbuhkembangkan minat kewirausahaan yaitu dengan cara mengubah mindset pemuda yang saat ini hanya berminat mencari pekerjaan tetapi belum berminat memiliki usaha sendiri. Hal tersebut menjadi sebuah tantangan bagi dunia pendidikan.Sejalan dengan hal tersebut maka pemerintah melalui Instruksi Presiden No. IV Tahun 1995 meresmikan adanya pengembangan kewirausahaan ke semua lapisan termasuk instansi baik pemerintah maupun swasta telah berlangsung hingga sekarang. Peresmian tersebut termotivasi dengan keadaan bangsa Indonesia sejak krisis ekonomi tahun 1997 hingga kini kita masih dihadapkan berbagai masalah. Sejak krisis ekonomi terjadi pada bangsa Indonesia hingga saat ini belum menunjukkan perubahan yang bermakna dan berakibat adanya PHK diberbagai perusahaan di Indonesia. Dalam hal lain lulusan perguruan tinggi sampai saat ini belum sepenuhnya mendapat lapangan pekerjaan, dengan hal itu berakibat pada banyaknya jumlah pengangguran terdidik di Indonesia. Lulusan perguruan tinggi saat ini dituntut untuk bersaing menciptakan lapangan pekerjaan bagi dirinya dan orang lain sehingga dapat mengurangi angka pengangguran di Indonesia.

Untuk menumbuhkembangakan jiwa kewirausahaan mahasiswa di Indonesia perguruan tinggi saat ini telah membuat kebijakan bahwa mata kuliah kewirausahaan merupakan mata kuliah yang wajib ditempu oleh mahasiswa. Pendidikan kewirausahaan menjadi faktor penting dalam menumbuhkan dan mengembangkan keinginan dan jiwa berwirausaha dikalangan generasi muda karena pendidikan merupakan sumber sikap dan niat keseluruhan untuk menjadi wirausahawan sukses di masa depan (Fatoki, 2014). Pendidikan kewirausahaan tidak hanya berdampak pada intelegensinya saja tetapi dapat membentuk sikap dan pola pikir seorang wirausaha. Hal ini merupakan investasi modal manusia untuk mempersiapkan para mahasiswa dalam memulai bisnis baru melalui integrasi pengalaman, keterampilan, dan pengetahuan penting untuk mengembangkan dan memperluas sebuah bisnis. Pendidikan kewirausahaan juga dapat meningkatkan minat para mahasiswa untuk memilih kewirausahaan sebagai salah satu pilihan karir selain pilihan karir menjadi pegawai swasta, PNS, atau pegawai BUMN di mana secara signifikan dapat mengarahkan sikap, perilaku, dan minat ke arah kewirausahaan.

Azwar (2013) menyatakan menumbuhkan jiwa kewirausahaan para mahasiswa perguruan tinggi dipercaya merupakan alternatif untuk mengurangi tingkat pengangguran, karena para sarjana diharapkan dapat menjadi wirausahawan muda terdidik yang mampu merintis usahanya sendiri karena dunia bisnis masa kini dan masa depan lebih mengandalkan knowledge dan intelectual capital, maka agar dapat menjadi daya saing bangsa, pengembangan wirausaha muda perlu diarahkan pada kelompok muda terdidik (intelektual). Pengetahuan kewirausahaan mendukung nilainilai wirausaha bagi mahasiswa, sehingga diharapkan mampu menumbuhkan jiwa untuk berwirausaha. Minat mahasiswa dan pengetahuan mereka tentang kewirausahaan diharapkan akan membentuk kecenderungan mereka untuk membuka usaha baru di masa mendatang. Wirausaha merupakan orang yang menciptakan sebuah bisnis yang berhadapan dengan risiko dan ketidakpastian, bertujuan memperoleh profit dan mengalami pertumbuhan dengan cara mengidentifikasi kesempatan dan memanfaatkan sumber daya yang diperlukan. Dewasa ini, banyak kesempatan untuk berwirausaha bagi setiap orang yang jeli melihat peluang bisnis tersebut. Karier kewirausahaan dapat mendukung kesejahteraan masyarakat yaitu menghasilkan imbalan finansial yang nyata (Agustina \& Sularto, 2011).

Untuk mendorong tumbuh dan berkembangnya jiwa wirausaha bagi mahasiiswa dan menciptakan lulusan yang dapat menciptakan lapangan pekerjaan. Mahasiswa 
diarahkan berbagai program dalam rangka menumbuhkan aktivitas wirausaha dalam lingkungan mahasiswa, seperti adanya mata kuliah kewirausahaan (KWU), Magang Kewirausahaan (MKU), Kuliah Kerja Usaha (KKU), dan kegiatan Karya Alternatif Mahasiswa (KAM) yang sekarang menjadi Program Kreativitas Mahasiswa, sekelompok mahasiswa didorong untuk menghasilkan perangkat atau barang produksi (baik perangkat keras maupun perangkat lunak, barang, dan jasa) yang dapat dimanfaatkan oleh masyarakat yang bernilai komersial.

Berdasarkan dari latar belakang tersebut, maka penulis akan mencoba untuk membuat sebuah tulisan yang akan membahas tentang pengembangan pembelajaran kewirausahaan di perguruan tinggi melalui Ve-Ice Carrolli untuk menumbuhkembangkan minat berwirausaha mahasiswa. Adapun tujuan dilaksanakannya penelitian ini adalah untuk menganalisis pengembangan pembelajaran kewirausahaan di perguruan tinggi melalui Ve-Ice Carrolli untuk menumbuhkembangkan minat berwirausaha mahasiswa.

\section{METODE}

Metode yang digunakan dalam penelitian ini yaitu studi kepustakaan, menurut Nazir (2003), mengemukakan bahwa "studi kepustakaan adalah teknik pengumpulan data dengan cara studi penelaahan terhadap buku-buku, literatur-literatur, catatancatatan, dan laporan-laporan yang ada hubungannya dengan masalah yang dipecahkan." Peneliti melakukan kajian yang berkaitan dengan teori yang berkaitan dengan topik penelitian, mengumpulkan informasi sebanyak-banyaknya dari kepustakaan yang berhubungan.

\section{HASIL DAN PEMBAHASAN}

Perkembangan teknologi di era 4.0 berdampak pada pola pikir manusia yang serba digital, baik bidang pendidikan, ekonomi, sosial dan sebagainya. Pada dunia pendidikan khususnya dalam perguruan tinggi erat kaitannya dengan tugas-tugas berkarya dalam dunia ilmiah, yaitu pada mata kuliah kewirausahaan mahasiswa dituntut untuk berwirausaha melalui progam kreatifitas mahasiswa.Kewirausahaan memiliki tiga tahapan. Tahap pertama yaitu proses meniru dan duplikasi (proses meniru tetapi juga mengembangkan apa yang ditiru). Tahap kedua yaitu tahap penciptaan Dan tahap terakhir yaitu tahap inovasi, dimana pada tahap ini barang/jasa yang baru di perbaharui lagi untuk menambah nilai tambah barang/jasa tersebut.

Menurut Yuliani, N dkk (2019) seorang wirausaha harus mempunyai bekal ilmu pengetahuan terkait usaha yang akan dirintis dan lingkungan usaha yang ada, peran dan tanggungjawab serta bekal manajemen dalam organisasi bisnis. Selain itu seorang wirausaha juga harus mempunyai bekal ketrampilan yaitu mengatur strategi, memperhitungkan segala resiko, menciptakan nilai tambah, memimpin dan mengelola, serta ketrampilan berinteraksi dan berkomunikasi.

Minat adalah perhatian khusus terhadap hal tertentu yang tercipta dengan penuh kemauan. Minat dapat menjadi motivasi yang kuat bagi seseorang untuk bertindak sesuatu dalam mewujudkan tujuan dan cita-cita yang hendak dicapai. Keinginan yang timbul dalam diri seseorang dapat menimbulkan suatu keinginan, suatu keinginan dapat ditandai dengan adanya rasa suka atau tidak suka, senang atau tidak senang. Mahasiswa yang memiliki minat pada suatu bidang akan memfokuskan perhatiannya lebih banyak dari pada mahasiswa yang tidak memiliki minat pada suatu bidang.Sesuai dengan pendapat dari Slameto (2003: 180), bahwa "Minat tidak dibawa sejak lahir,melainkan diperoleh kemudian. Minat terhadap sesutu merupakan hasil belajar dan menyokong belajar selanjutnya". Hal ini menggambarkan bahwa minat dapat ditumbuhkan dan dikembangkan. Minat tidak bisa timbul denga sendirinya, minat dapat timbul melalui diri seseorang melalui proses. Dengan adanya perhatian dan interaksi dengan lingkungan, maka minat tersebut dapat berkembang. Munculnya minat 
seseorang ditandai adanya rasa keinginan dan dorongan yang kuat pada suatu bidang tertentu.

Melalui pembelajaran kewirausahaan di perguruan tinggi mahasiswa diharapakan mampu menegembangkan ilmu yang sudah di dapatkan dibangku kuliah. Sebagai salah satu bentuk pengembangan pembelajaran Kewirausahaan di perguruan tinggi yang dapat menumbuhkembangkan minat berwirausaha mahasiswa yaitu melalui Progam Kreatifitas Mahasiswa Kewirausahaan (PKM-K). PKM merupakan salah satu upaya yang dilakukkan Kemenristekdikti untuk meningkatkan kualitas mahasiswa di perguruan tinggi. Realisasi PKM dimaksudkan agar kelak dapat menjadi anggota masyarakat yang memiliki kemampuan akademis dan/atau profesional yang dapat menerapkan, mengembangkan dan meyebarluaskan ilmu pengetahuan, teknologi dan/atau kesenian serta memperkaya budaya nasional. Dalam rangka mempersiapkan diri menjadi pemimpin yang cendekiawan, wirausahawan serta berjiwa mandiri dan arif, mahasiswa diberi peluang untuk mengimplementasikan kemampuan, keahlian, sikap, tanggungjawab, membangun kerjasama tim maupun mengembangkan kemandirian melalui kegiatan yang kreatif dalam bidang ilmu yang ditekuni.Program Kreativitas Mahasiswa Kewirausahaan (PKM-K) merupakan program pengembangan keterampilan mahasiswa dalam berwirausaha dan berorientasi pada laba (profit).

Ve-Ice Carroli (Vegetables Ice cream Carrot and Brokoli) adalah salah satu judul PKM K yang lolos pendanaan pada tahun 2019 di Universitas Sebelas Maret. Ide tersebut dilatarbelakangi karena membidik perkembangan pasar es krim Indonesia sangat besar secara ukuran, mencapai 158 juta liter dan terbesar di Asia Tenggara. Ini lantaran jumlah penduduk Indonesia yang besar. Proyeksinya, hingga tahun 2018 pertumbuhan pasar es krim mencapai 240 juta liter atau rata-rata tumbuh $8,75 \%$. (Marketeers, 2018). Jika pertumbuhan pasar terus meningkat maka produksi pasar es krim akan naik dan permintaan pasar semakin banyak. Pasar es krim di Indonesia saat ini hampir semua memproduksi es krim dengan varian rasa yang paling digemari masyarakat yaitu es krim yang berbahan dasar dari coklat. Hal ini menjadi peluang bisnis yang perlu dikembangkan karena es krim merupakan makanan yang banyak digemari oleh masyarakat. Melihat karakteristik masyarakat masa kini yang memiliki ketertarikan dengan hal baru, oleh karena itu kami berinovasi membuat VE-ICE CARROLI: Vegetables Ice Cream Carrot and Brocoli dimana produk ini merupakan es krim berbahan dasar sayur yang memiliki keunikan rasa dengan memanfaatkan sayur wortel dan brokoli untuk produk olahan es krim. Strategi pemasaran untuk produk VEICE CARROLI memanfaatkan teknologi digital seperti media sosial (facebook, instagram, whatsapp, twitter).

Bertititk tolak dari uraian diatas, mahasiswa diharapkan mempunyai sikap yang selalu berfikir positif, bersikap percaya diri, berani mengambil setiap resiko yang ada, berjiwa pemimpin, selalu berorientasi ke depan, dan berorientasi pada hasil. Jiwa seorang wirausaha selalu berusaha mencari, memanfaatkan, dan menciptakan peluang usaha yang dapat memberikan keuntungan baik untuk diri sendiri maupun untuk orang lain. Wirausaha sangat membantu perekonomian masyarakat, karena wirausaha mampu membuka lapangan pekerjaan. Bagi wirausaha risiko kerugian merupakan hal biasa karena mereka memegang prinsip bahwa faktor kerugian pasti ada. Risiko bukanlah untuk dihindari, melainkan untuk dihadapi dan ditaklukan dengan penuh perhitungan.

\section{SIMPULAN}

Salah satu bentuk pengembangan pembelajaran Kewirausahaan di perguruan tinggi yang dapat menumbuhkembangkan minat berwirausaha mahasiswa yaitu melalui Progam Kreatifitas Mahasiswa Kewirausahaan (PKM-K) yang berjudul Ve-Ice Carrolli sehingga dapat mempunyai sikap yang selalu berfikir positif, bersikap percaya diri, berani mengambil setiap resiko yang ada, berjiwa pemimpin, selalu berorientasi ke 
depan, dan berorientasi pada hasil. Jiwa seorang wirausaha selalu berusaha mencari, memanfaatkan, dan menciptakan peluang usaha yang dapat memberikan keuntungan baik untuk diri sendiri maupun untuk orang lain.

\section{DAFTAR PUSTAKA}

Agustina, C., dan Sularto, L. (2011). Intensi kewirausahaan mahasiswa (Studi perbandingan antara fakultas ekonomi dan fakultas ilmu komputer). Proceeding PESAT (Psikologi, Ekonomi, Sastra, Arsitektur, \& Sipil) Universitas Gunadarma, Depok, 18-19 Oktober 2011, 4: E.63-E.69.

Azwar, Budi. (2013). Analisis Faktor-faktor yang Mempengaruhi Niat Kewirausahaan (Entrepreneurial Intention). Studi Terhadap Mahasiswa Universitas Islam Negeri SUSKA Riau. Menara, 12(1): 12-22.

Marketeers. (2018). Lezatnya Potensi Pasar Es Krim Indonesia. Diunduh dari marketeers.com/lezatnya-potensi-pasar-es-krim-indonesia/ Pada tanggal 25 September 2019.

Yuliani, N.,dkk. (2019). Menumbuhkan Jiwa Wirausaha Kawula Mudadi Era Milenial Melalui Pendekatan Inside-Out. Vol 2 No 2 Bulan Juli 2019. Diakses dari https://media.neliti.com/media/publications/268416-menumbuhkan-iiwawirausaha-kawula-mudadi-8c70e932.pdf. 